\title{
The diet of white-chinned petrels Procellaria aequinoctialis, Linnaeus 1758, in years of contrasting prey availability at South Georgia
}

\author{
SIMON D. BERROW and JOHN P. CROXALL \\ British Antarctic Survey, Natural Environmental Research Council, High Cross, Madingley Road, Cambridge CB3 OET, UK
}

\begin{abstract}
The diet of breeding white-chinned petrels was studied during the summers of 1996 and 1998 at South Georgia. Krill abundance/availability was high throughout 1996 but apparently low at the beginning of the 1998 breeding season. The diet of white-chinned petrels was similar between years and consistent with previous studies. Krill Euphausia superba (41-42\% by weight) was the single most important prey item followed by fish (39-29\%) and squid (19-25\%). Meal mass was consistent (110 g in 1996, $119 \mathrm{~g}$ in 1998) between years but a significant decrease $(46 \%)$ in feeding frequency in $1998\left(0.54\right.$ meals day ${ }^{-1}$ compared to 0.75 meals day $^{-1}$ in 1996) resulted in $19 \%$ less food delivered to chicks in 1998 than in 1996 . Breeding success, however, was consistent between years at $44 \%$ and similar to that recorded previously at Bird Island. This is in contrast to black-browed and grey-headed albatrosses, both of which experienced almost total breeding failure in 1998. It is suggested that their varied and versatile feeding methods, together with their greater diving ability, capacity to feed at night and extensive foraging range, help white-chinned petrels minimise the effects of krill shortage.
\end{abstract}

Received 21 December 1998, accepted 5 May 1999

Key words: diet, feeding frequency, inter-annual variation, krill, meal size, white-chinned petrel

\section{Introduction}

An estimated 70 million seabirds breed at South Georgia and consume around 7.8 million tonnes of food annually of which 73\% is Antarctic krill Euphausia superba Dana 1852(Croxall $\&$ Prince 1987). The dependence of so many seabirds on a single prey item has led to speculation as to how this resource is partitioned between species. Croxall et al. (1997) suggested that a combination of differences in diet, feeding methods, foraging behaviour and foraging range of seabirds breeding at South Georgia operate to promote a degree of ecological segregation. The abundance of krill at South Georgia and its availability to marine predators exhibits strong seasonal and inter-annual variation (Priddle et al. 1988, Boyd et al. 1994, Croxall et al. 1999). In most years there may be enough food available to generate only low levels of interspecies competition; however, competition may be intense in years when this food resource is scarce (Croxall et al. 1997, 1999).

The white-chinned petrel Procellaria aequinoctialis Linnaeus 1758 , with a breeding population of c. 2 million birds (Croxall et al. 1984), is the third most important avian consumer of krill at South Georgia and the most important avian consumer of fish and squid (Croxall et al. 1995). Despite this role its diet has only been studied in detail during a single season and in a year (1986) of high krill availability (Croxall et al. 1995, 1997, 1999). Species with an apparently similar diet, such as the grey-headed albatross Diomedea chrysostoma Forster 1785 and Antarctic prion Pachyptila desolata Gmelin 1789, exhibit significant inter-annual variation in the proportion of krill and other prey species in their diet
(Prince 1980, Liddle 1994, Reid et al. 1997). However, the mixed diet of these species seems to act to reduce inter-annual variability in breeding success, in comparison with species more dependent on krill (Liddle 1994, Croxall et al. 1998 , 1999). Here we present data on the diet, meal size and feeding frequency of white-chinned petrels during two summers of contrasting krill availability in order to evaluate the response of white-chinned petrels to variations in food supply.

\section{Methods \\ Collection of food samples}

Food samples were collected from 8 February-25 March 1996 and between 10 January-25 February 1998 on Bird Island, South Georgia $\left(54^{\circ} 01^{\prime} \mathrm{S}, 38^{\circ} 03^{\prime} \mathrm{W}\right)$. Adults were captured at dusk as they landed near their breeding burrow, held over a large funnel $(200 \mathrm{~mm}$ diameter $)$ which drained into a plastic bag and induced to regurgitate. Occasionally adults had to be gently massaged around their stomach to encourage vomiting, but often they regurgitated on handling, sometimes before they could be positioned over the funnel; in these instances the liquid fraction of the food sample was lost. Chicks that had been fed during the night, as determined from twice daily weighings, were food sampled the following morning. Chicks were removed from their nest through a removable cover over the nest chamber or by reaching into the nest from the tunnel entrance. Samples were collected from 
20 adults and 20 chicks in 1996 and 10 adults and 30 chicks in 1998.

\section{Analysis of food samples}

Food samples were analysed according to Croxall et al. (1995). For samples where the entire food sample was collected, the liquid fraction was drained off before sorting and the proportion by weight of this fraction calculated. The resultant food mass was sorted into three components: squid, fish and crustaceans (euphausiids, amphipods and decapods) and each component weighed. Any remaining unidentifiable material was weighed and assumed to occur in the same proportion as identifiable remains and was added pro-rata to their total mass.

Cephalopod beaks were removed and stored in alcohol for later analysis. Fish otoliths were removed, counted and identified using Williams \& McEldowney (1990), Hecht (1987) and Reid (1996). Left and right otoliths were matched if their length was within one graticule unit $(0.15 \mathrm{~mm}$, inserted in a binocular microscope at $\times 6.5$ magnification) and the minimum number of fish in the sample calculated. Fish length was calculated using the regressions in Croxall et al. (1995) and Reid (1996), using the otolith erosion categories described in Reid \& Arnould (1996). For Patagonotothen guntheri Norman 1937 the relationship between fish length (TL) and mass (TW) was described by the equation

$$
\mathrm{TW}=0.396 \mathrm{TL}-32.7\left(n=50, r^{2}=0.95\right)
$$

(M. White unpublished data). No regression equation was available for the Macrouridae recovered in 1998. The number of squid in food samples was calculated from the number of upper or lower beaks (whichever was greater) and crustaceans from pairs of eyes. Intact krill carapaces were removed, stored in alcohol and measured under a binocular microscope; the generalized regression in Hill (1990) was used to estimate total body length.

\section{Provisioning rate and meal size}

Provisioning rate was determined in both years over a ten day period between 4-14 February, just after the chick brooding period finished and at the start of their period of rapid linear growth (Hall 1987). Chicks were weighed within one hour of dusk and up to one hour after dawn using Pesola ${ }^{\circledR}$ spring balances. Following Croxall et al. (1995), a feed was recorded when there was a mass increase over the previous weighing in excess of $1 \%$ of the balance capacity. For consistency with Croxall et al. (1995), meals in excess of $300 \mathrm{~g}$ were assumed to result from two feeds between weighings and were excluded from meal size analyses but were recorded as two feeds for provisioning rate analyses. This occurred on four occasions in $1996(360-540 \mathrm{~g})$ and once $(450 \mathrm{~g})$ in 1998 . Meal size data obtained from adults was corrected for $15 \%$ residual stomach contents after Croxall et al. (1995).

\section{Results}

\section{Meal size and provisioning rate}

The size of meal recovered from both adult birds and chicks in 1996 and 1998 is shown in Table I. There was no difference in meal size from chicks and adults in 1996 (Mann-Whitney test, $U=407$, NS) but in 1998 meal sizes from chicks were significantly larger than those obtained from adults $(U=107$, $P<0.05)$. Although not significantly smaller $(U=334.5$, NS), adult samples from 1998 weighed only $79 \mathrm{~g}$ compared with $109 \mathrm{~g}$ in 1996 . When meal sizes in each year were combined they averaged $110 \mathrm{~g}$ in 1996 and $119 \mathrm{~g}$ in 1998 and were not significantly different ( $U=1518$, NS). These estimates of meal size were 14-22 g (11-16\%) less than that recorded in 1986 by Croxall et al. (1995) (Table I). Mean meal sizes as determined from twice daily chick weighings were greater by $18-27 \%$ than meals from adults, although this was not significantly different in either year (two-sample $t$-test, 1996:

Table I. Mean meal size (range, sample size in parentheses) from food samples and 12 hourly chick weighings and mean feeding frequency of white-chinned petrels at Bird Island, South Georgia (1986 data from Croxall et al. 1995)

\begin{tabular}{|c|c|c|c|c|}
\hline & & 1986 & 1996 & 1998 \\
\hline \multirow[t]{4}{*}{ Meal size $(\mathrm{g})$} & Adult ${ }^{1}$ & $\begin{array}{c}147.7 \pm 61.7 \\
(49-300, n=74)\end{array}$ & $\begin{array}{c}109.5 \pm 46.3 \\
(43-222, n=20)\end{array}$ & $\begin{array}{c}79.0 \pm 33.8 \\
(40-136, n=10)\end{array}$ \\
\hline & Chick & - & $\begin{array}{c}111.1 \pm 54.2 \\
(27-221, n=20)\end{array}$ & $\begin{array}{c}131.4 \pm 61.7 \\
(33-249, n=30)\end{array}$ \\
\hline & All diet samples & $\begin{array}{c}131.9 \pm 65.4 \\
(26-300, n=91)\end{array}$ & $\begin{array}{c}110.3 \pm 49.4 \\
(27-222, n=40)\end{array}$ & $\begin{array}{c}118.6 \pm 60.2 \\
(33-249, n=40)\end{array}$ \\
\hline & $12 \mathrm{hr}$ weighings & $\begin{array}{c}167.1 \pm 74.3 \\
(37-477, n=477)\end{array}$ & $\begin{array}{c}130.4 \pm 64.8 \\
(30-290, n=77)\end{array}$ & $\begin{array}{c}146.3 \pm 70.5 \\
(30-300, n=53)\end{array}$ \\
\hline \multirow[t]{3}{*}{$\begin{array}{l}\text { Feeding frcquency } \\
\left(\text { meals day }{ }^{-1}\right)\end{array}$} & Mean $\pm s d$ & $\begin{array}{c}0.69 \\
(0.30-0.98, n=212)\end{array}$ & $\begin{array}{c}0.75 \\
(0.50-1.0, n=81)\end{array}$ & $\begin{array}{c}0.54 \\
(0.30-0.80, n=55)\end{array}$ \\
\hline & $\%$ feeds in day & - & 30.9 & 50.1 \\
\hline & $\%$ feeds at night & - & 69.1 & 49.9 \\
\hline
\end{tabular}

'corrected for $15 \%$ residual stomach contents (Croxall et al. 1995) 
$\left.t_{85}=1.66, \mathrm{NS}, 1998: t_{83}=1.97, \mathrm{NS}\right)$.

Chicks selected for monitoring had a mean ( $\pm \mathrm{sd}$ ) body mass of $541 \pm 31 \mathrm{~g}$ (range: $315-640, n=11$ ) in 1996 and $496 \pm 38 \mathrm{~g}$ (range: $320-680, n=11)$ in $1998\left(\mathrm{t}_{20}=3.04, P<0.01\right)$. Feeding frequency over the 10 day weighing period varied from $0.50-1.0$ meals per day per chick in 1996 and $0.30-0.80$ in 1998 (Table I). Chicks were fed every 1.3 days in 1996, significantly more often than the 1.9 days in 1998 (MannWhitney test, $U=83, P<0.01$ ). A feeding frequency of 0.69 meals day ${ }^{-1}$ was reported by Croxall et al. (1995) from 1986; this is intermediate between our values for $1996(0.75)$ and 1998 (0.54) (Table I). However using $300 \mathrm{~g}$ as a threshold above which mass increases represent two feeds will underestimate true feeding frequency. If a threshold of $200 \mathrm{~g}$ is used (i.e. slightly less than twice the average meal size in 1996 and 1998) then estimates of feeding frequency increase to 0.84 in 1996 and 0.63 in 1998 (one meal every 1.2 days in 1996 and 1.6 days in 1998). However, chicks were still fed $25 \%$ more often in 1996 compared to 1998 . The total food fed to each chick over the 10 day period was, on average, $34 \%$ greater in 1996 (1027 g, range: 680-1320 g) than in 1998 (764 g, range: $470-1180 \mathrm{~g}$ ). Mean provisioning rate $\left(\mathrm{g} \mathrm{day}^{-1}\right)$, using all diet samples as a measure of meal size, was $82.7 \mathrm{~g}$ in 1996 and $64.0 \mathrm{~g}$ in $1998,91 \%$ and $70 \%$ of the value of $91.0 \mathrm{~g}$ day $^{-1}$ reported from 1986. Mean total food intake can be calculated from mean feeding frequency $\times$ mean meal size $x$ fledging period for a fledging period of 98 days (Hall 1987). Chicks were estimated to receive $11.30 \mathrm{~kg}$ in $1986,9.58 \mathrm{~kg}$ in 1996 and $7.74 \mathrm{~kg}$ in 1998.

As chicks were weighed at dawn and dusk we could determine whether chicks were fed during the night or during daylight. In 1996 around two-thirds of meals (69\%) were delivered during the night, compared with only one half during 1998 (Table I).

\section{Composition of food samples}

The mean liquid content ( $\pm \mathrm{s}$ d) of twenty five food samples obtained from the 1998 chick regurgitates was $36.8 \pm 12.7 \%$ (range: $16.5-62.2 \%$ ). Only one intact sample was obtained from adult birds during 1998 (with a liquid fraction of $40.9 \%$ ) and four during 1996 (mean $21.3 \pm 2.9 \%$, range: $15.2-27.5 \%$ ). Euphausiids accounted for the largest proportion by mass and frequency of occurrence in all years, followed by fish and squid (Fig. 1). There were small differences in the relative
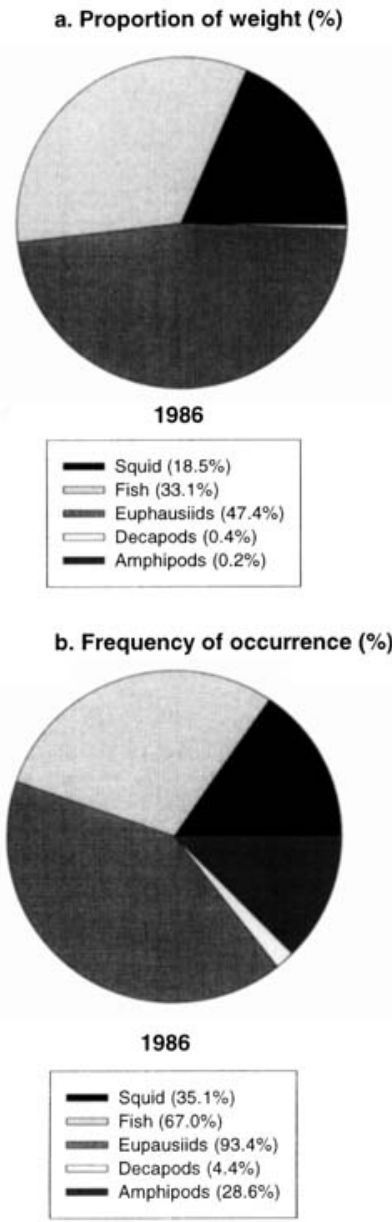
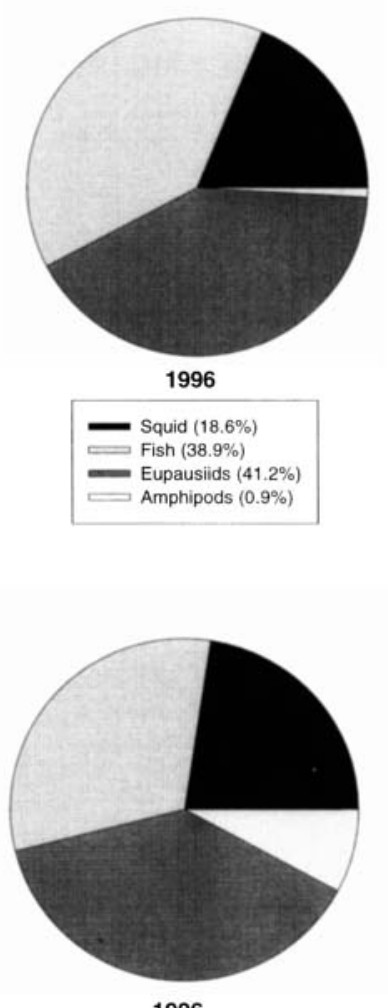

1996

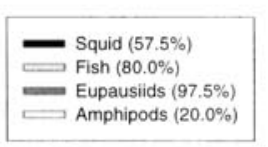

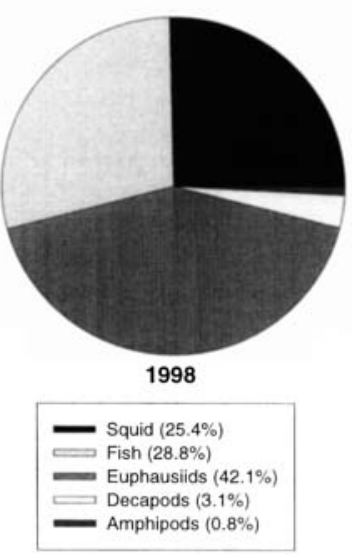

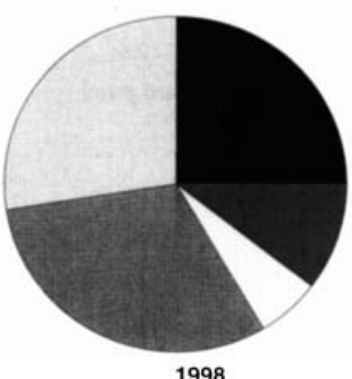

1998

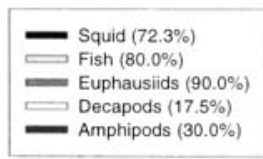

Fig. 1. Composition of the diet of white-chinned petrels during three summers at Bird Island, South Georgia a. as a proportion of total weight and $\mathbf{b}$. frequency of occurence. 
proportions of each major food type between the three years studied but these were not significant $\left(\chi_{4}^{2}=0.49, \mathrm{NS}\right)$. In 1996 and 1998 the proportion of euphausiids by mass was constant at $41-42 \%$ but squid occupied a greater proportion of the diet of white-chinned petrels in 1998 (25.4\%) compared to 1986 and $1996(18.6 \%)$ and also occurred in more samples in 1998 (72.3\%). The proportion of fish decreased from $38.9 \%$ in 1996 to $28.8 \%$ in 1998 .

\section{Crustaceans}

All identifiable remains of crustaceans were krill, the amphipod Themisto gaudichaudii Guérin, 1825 and the decapod Notocrangon antarcticus Pfeffer 1887. Krill occurred in 39 of the 40 samples in 1996 and 36 of the 40 samples obtained in 1998. If the total number of all individuals is calculated, euphausiids accounted for $87.2 \%$ of prey items in 1996 $(n=1308)$ and $86.7 \%(n=1237)$ in 1998. The lengthfrequency distributions of krill (estimated from intact carapaces) are shown in Fig. 2. The mean length ( $\pm \mathrm{se}$ ) was $47.2 \pm 1.0 \mathrm{~mm}$ (range: $35.4-60.0$ ) in 1996 and $46.1 \pm 0.9 \mathrm{~mm}$ (range: 33.1-60.7) in 1998. The modal length was smaller in $1996(39-41 \mathrm{~mm})$ compared to $1998(42 \mathrm{~mm})$ but there was no significant difference in krill length-frequency distributions (Kolmogorov-Smirnov one tailed test, $D=0.20$, NS). Comparing the length-frequency distribution of krill recovered from white-chinned petrels to those of krill caught in scientific trawl nets (RMT) (Fig. 2) off the western end of South Georgia research cruises (JR11 and JR28) shows that white-chinned petrels fed on the larger krill in the area (KolmogorovSmirnov one tailed test, 1996: $D=0.25, P<0.01,1998$ : $D=0.21, P<0.01)$. White-chinned petrels consumed more
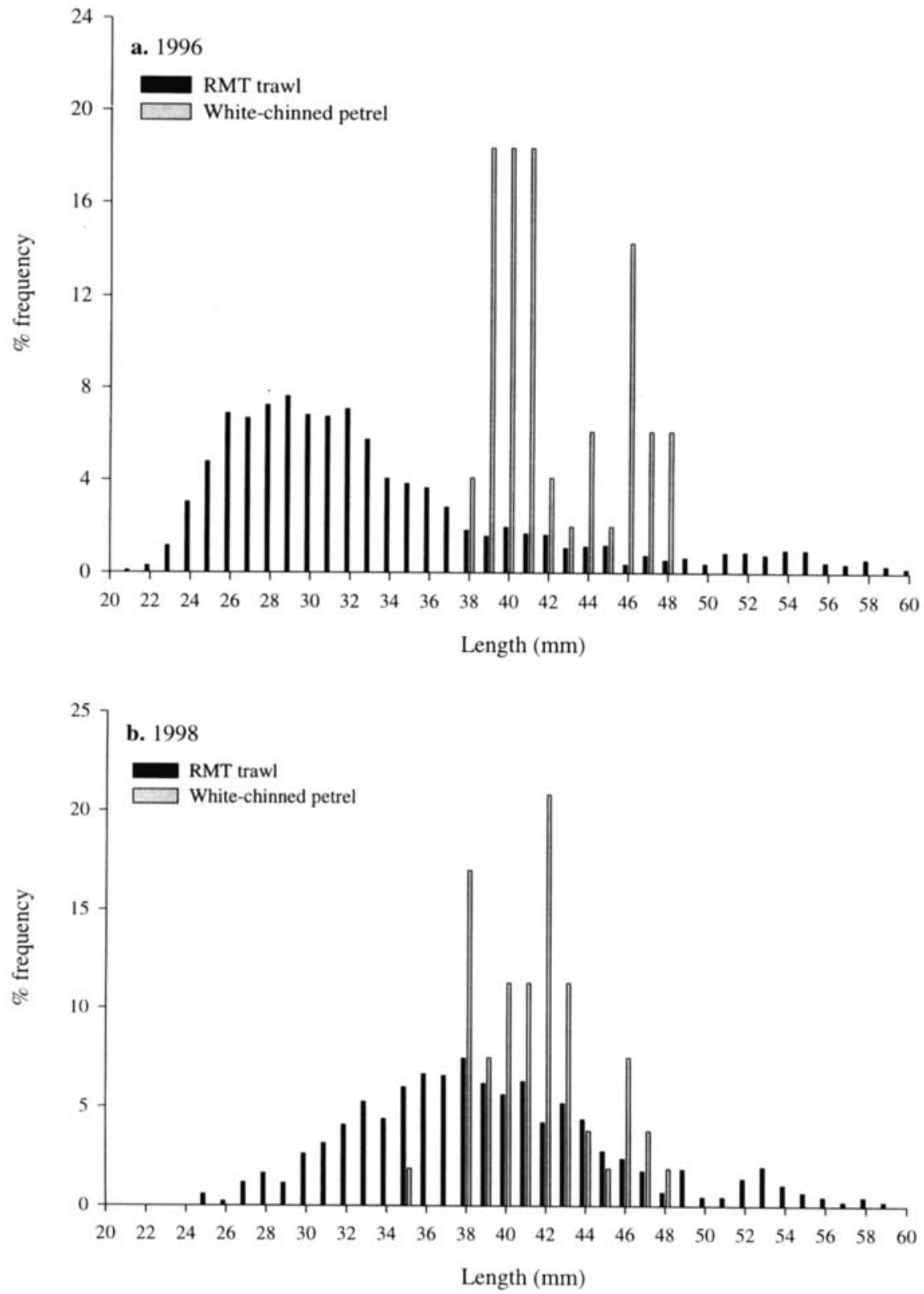

Fig 2. Length-frequency distribution of Antarctic krill from whitechinned petrel food samples in the summer and from trawl catches around South Georgia. a. 1996 $(n=49)$ and b. $1998(n=53)$. 
decapods in $1998(3.1 \%)$, compared to $<1 \%$ in 1986 and 1996; the proportion of amphipods was $<1 \%$ in all years studied.

\section{Squid}

In 1996, only six beaks (two of which were unidentifiable) were recovered from white-chinned petrel food samples despite squid flesh occurring in 23 of the 40 samples (57.5\%). Each of the four beaks belonged to a different species (Table II): Illex argentinus (Castellanos 1960), Mastigoteuthis psychrophila (Nesis 1977), Psychroteuthis glacialis Thiele 1921 and Histioteuthis B (probably Histioteuthis eltaninae Voss 1969). In 1998, when squid occurred in 16 of the 40 samples (40\%), 43 beaks were recovered representing 3.5\% of all identifiable prey items $(n=1237)$. Brachioteuthis? picta Chun 1910 (identified from Rodhouse et al. 1991) was the most frequently recorded squid species, occurring in one third of the samples with identifiable squid but, due to its small size, accounted for only $3 \%$ of the total mass (Table II). Although a single specimen of Kondakovia longimana Filippova 1971 accounted for nearly $30 \%$ of the total mass of squid recovered in 1998, Galiteuthis glacialis Chun1906 was the most important squid species, occurring in $25 \%$ of samples and accounting for $21 \%$ of the total mass.

\section{Fish}

The frequency of occurrence of fish species in food samples from 1996 and 1998 is shown in Table III. In both years lantern fish (Myctophidae) accounted for most of the otoliths recovered followed by notothenids. Myctophids alone were found in $67 \%$ of samples from adults with otoliths in 1996 $(n=9)$ and 20\% in $1998(n=5)$. Notothenids were found exclusively in $22 \%$ of samples in 1996 and $40 \%$ in 1998, with both myctophids and notothenids in only one adult sample in each year.
Eleven species of fish were identified from the 146 otoliths recovered in 1996 with the notothenid Lepidonotothen larseni Loennberg 1905 being the most numerous, accounting for $31 \%$. The two myctophid species Electrona antarctica Günther 1878 and Gymnoscopelus nicholsi Gilbert 1911 occurred in more food samples but in smaller numbers. Although only about one half the number of otoliths were found in 1998 as in 1996, twelve fish species were identified. Electrona antarctica Günther 1878 and $E$. carlsbergi Taning 1932 were the most abundant myctophid species and Patagonotothen guntheri and Lepidonotothen larseni the most abundant notothenids (Table III). Species from the genus Gymnoscopelus were frequent in both years but especially in 1996. In 1996 one sample was dominated by Muraenolepis australis Norman 1937; individuals of the family Macrouridae were identified in a single sample from 1998.

\section{Discussion}

Diet

The diet and feeding ecology of white-chinned petrels at South Georgia was first described by Croxall et al. (1995). They showed that although krill was the most important prey type, squid and fish were also frequently consumed, contributing about $51.6 \%$ of the overall diet even in 1986 a year of high local krill abundance. When compared to the diet of white-chinned petrels at breeding sites in the Indian and Pacific Oceans (Jackson 1988, Cooper et al. 1992), birds at South Georgia differed in that squid was the least and crustaceans the most important constituent of the diet. From a single year study, Croxall et al. (1995) were uncertain whether the predominance of krill in white-chinned petrel diet at South Georgia reflected the greater abundance and availability of krill (relative to fish and squid) around South Georgia than in the Indian Ocean or whether the year studied (1986) was a year when krill was in greater abundance/

Table II. Composition of the squid component of the diet of white-chinned petrel on Bird Island, South Georgia during the 1996 and 1998 summers.

\begin{tabular}{|c|c|c|c|c|c|c|c|c|c|c|c|c|}
\hline & \multirow[t]{2}{*}{ Species } & \multirow{2}{*}{$\begin{array}{l}\text { Frequency of } \\
\text { occurrence } \\
(\%)\end{array}$} & \multicolumn{2}{|c|}{ Beaks } & \multicolumn{2}{|c|}{$\begin{array}{l}\text { Beak length } \\
(\mathrm{mm})\end{array}$} & \multicolumn{2}{|c|}{$\begin{array}{c}\text { Estimated Mantle } \\
\text { length (mIn) }\end{array}$} & \multicolumn{4}{|c|}{$\begin{array}{c}\text { Estimated Mass } \\
\text { (g) }\end{array}$} \\
\hline & & & No & $\%$ & Mode & Range & Mean $\pm \mathrm{se}$ & Range & Mean $\pm \mathrm{se}$ & Range & Total & $\%$ \\
\hline \multirow[t]{5}{*}{$1995-96$} & Illex argentinus & 25.0 & 1 & 17 & 3.3 & - & 209.8 & - & 104.9 & - & 104.9 & 30.1 \\
\hline & Mastigoteuthis psychrophila & la 25.0 & 1 & 17 & 4.5 & - & 132.1 & - & 90.3 & - & 90.3 & 25.9 \\
\hline & Psychroteuthis glacialis & 25.0 & 1 & 17 & 4.2 & - & 153.4 & - & 78.2 & - & 78.2 & 22.4 \\
\hline & Histioteuthis $B$ & 25.0 & 1 & 17 & 3.3 & - & 58.8 & - & 75.5 & - & 75.5 & 21.6 \\
\hline & Unidentifiable & - & 2 & 33 & - & - & - & - & - & - & - & - \\
\hline \multirow[t]{8}{*}{$1997-98$} & Brachioteuthis? picta & 33.3 & 8 & 18 & 3.0 & $2.7-3.4$ & $78.5 \pm 1.6$ & $70.6-83.5$ & $8.5 \pm 0.3$ & $7.55-9.85$ & 67.8 & 3.0 \\
\hline & Galiteuthis glacialis & 25.0 & 6 & 13 & 4.4 & $4.30-5.4$ & $176.0 \pm 29.4$ & $187.6-233.6$ & $79.6 \pm 7.2$ & $67.1-108.5$ & 477.8 & 21.2 \\
\hline & Mlex argentinus & 16.6 & 4 & 9 & 2.8 & $2.31-3.3$ & $202.0 \pm 2.9$ & $193.1-208.9$ & $74.4 \pm 10.4$ & $43.9-101.1$ & 297.5 & 13.2 \\
\hline & Histioteuthis $B$ & 12.5 & 3 & 7 & 3.8 & $3.02-3.9$ & $67.2 \pm 5.8$ & $53.1-75.6$ & $96.5 \pm 136$ & $63.3-113.5$ & 289.6 & 12.8 \\
\hline & Gonatus antarcticus & 8.3 & 2 & 4 & $5.6-6.2$ & $5.60-6.2$ & 210.4 & $196.7-224.1$ & 196.1 & $161.1-231.0$ & 392.1 & 17.4 \\
\hline & Kondakovia longimana & 4.2 & 1 & 2 & 10.2 & - & 386.6 & - & 671.5 & - & 671.5 & 29.7 \\
\hline & Chiroteuthis sp. & 4.2 & 1 & 2 & 5.0 & - & 134.7 & - & 61.9 & - & 61.9 & 2.7 \\
\hline & Unidentifiable & - & 18 & 40 & - & - & - & - & - & - & - & - \\
\hline
\end{tabular}

'of the food samples with identifiable squid, $1996=4,1998=16$. 
Table III. Frequency of occurrence of fish and their length $(\mathrm{mm})$ and mass $(\mathrm{g})$ estimated from otolith dimensions in white-chinned petrel food samples from Bird Island, South Georgia during the 1996 and 1998 summers.

\begin{tabular}{|c|c|c|c|c|c|c|c|c|c|c|c|}
\hline & \multirow[t]{2}{*}{ Species } & \multirow[t]{2}{*}{$\begin{array}{l}\text { freq } \\
(\%)\end{array}$} & \multirow[t]{2}{*}{$\begin{array}{c}\text { No. of } \\
\text { otoliths } \\
(\%)\end{array}$} & \multirow{2}{*}{$\begin{array}{c}1995-96 \\
\text { Estimated } \\
\text { Mean } \\
\text { (range) } \\
\text { fish length } \\
(\mathrm{mm})\end{array}$} & \multicolumn{2}{|c|}{$\begin{array}{c}\text { Estimated } \\
\text { fish mass } \\
\text { (g) }\end{array}$} & \multirow[t]{2}{*}{$\begin{array}{l}\text { freq } \\
(\%)\end{array}$} & \multirow{2}{*}{$\begin{array}{c}\text { No. of } \\
\text { otoliths } \\
(\%)\end{array}$} & \multirow{2}{*}{$\begin{array}{c}1997-98 \\
\text { Estimated } \\
\text { Mean } \\
\text { (range) } \\
\text { fish length } \\
(\mathrm{mm})\end{array}$} & \multicolumn{2}{|c|}{$\begin{array}{l}\text { Estimated } \\
\text { fish mass } \\
\text { (g) }\end{array}$} \\
\hline & & & & & $\begin{array}{l}\text { Mean } \\
\text { (range) }\end{array}$ & $\begin{array}{l}\text { Total } \\
(\%)\end{array}$ & & & & Mean & $\begin{array}{l}\text { Total } \\
(\%)\end{array}$ \\
\hline \multirow[t]{6}{*}{ Notothenidae } & Patagonotothen guntheri & 10.0 & $\begin{array}{c}2 \\
(1.4)\end{array}$ & $\begin{array}{c}169 \\
(166-171)\end{array}$ & $\begin{array}{c}34 \\
(33-35)\end{array}$ & $\begin{array}{c}103 \\
(4.1)\end{array}$ & 31.8 & $\begin{array}{c}6 \\
(9.5)\end{array}$ & $\begin{array}{c}191 \\
(156-226)\end{array}$ & $\begin{array}{c}43 \\
(29-56)\end{array}$ & $\begin{array}{c}230 \\
(16.5)\end{array}$ \\
\hline & Gobionotothen gibberfrons & 3.3 & $\begin{array}{c}1 \\
(0.7)\end{array}$ & 115 & 9 & $\begin{array}{c}9 \\
(0.4)\end{array}$ & 9.1 & $\begin{array}{c}2 \\
(3.2)\end{array}$ & $\begin{array}{c}180 \\
(178-182)\end{array}$ & $\begin{array}{c}43 \\
(41-45)\end{array}$ & $\begin{array}{c}86 \\
(6.2)\end{array}$ \\
\hline & Lepidonothen larseni & 26.7 & $\begin{array}{c}44 \\
(30.6)\end{array}$ & $\begin{array}{c}124 \\
(40-148)\end{array}$ & $\begin{array}{c}18 \\
(1-29)\end{array}$ & $\begin{array}{c}804 \\
(32.3)\end{array}$ & 27.3 & $\begin{array}{c}6 \\
(9.5)\end{array}$ & $\begin{array}{c}155 \\
(99-201)\end{array}$ & $\begin{array}{c}41 \\
(9-75)\end{array}$ & $\begin{array}{c}243 \\
(17.5\end{array}$ \\
\hline & Gobionotothen marionensis & - & - & - & - & - & 4.5 & $\begin{array}{c}3 \\
(4.8)\end{array}$ & $\begin{array}{c}173 \\
(138-194)\end{array}$ & $\begin{array}{c}47 \\
(22-63)\end{array}$ & $\begin{array}{c}141 \\
(10.1 ;\end{array}$ \\
\hline & Puranotothenia magellanica & - & - & - & - & - & 4.5 & $\begin{array}{c}1 \\
(1.6)\end{array}$ & 111 & 30 & $\begin{array}{c}30) \\
(2.1)\end{array}$ \\
\hline & Unidentified Notothenidae & 10.0 & $\begin{array}{c}3 \\
(2.1)\end{array}$ & - & - & - & - & - & - & - & \\
\hline \multirow[t]{9}{*}{ Myctophidae } & Electrona antarctica & 30.0 & $\begin{array}{c}19 \\
(13.2)\end{array}$ & $\begin{array}{c}72 \\
(42-156)\end{array}$ & $\begin{array}{c}8 \\
(1-53)\end{array}$ & $\begin{array}{c}154 \\
(6.2)\end{array}$ & 27.3 & $\begin{array}{c}6 \\
(9.5)\end{array}$ & $\begin{array}{c}69 \\
(62-112)\end{array}$ & $\begin{array}{c}6 \\
(1-19)\end{array}$ & $\begin{array}{c}38 \\
(2.7)\end{array}$ \\
\hline & Electrona carlsbergi & 16.7 & $\begin{array}{c}11 \\
(7.6)\end{array}$ & $\begin{array}{c}82 \\
(53-102)\end{array}$ & $\begin{array}{c}5 \\
(1-8)\end{array}$ & $\begin{array}{c}50 \\
(2.0)\end{array}$ & 31.8 & $\begin{array}{c}17 \\
(27.0)\end{array}$ & $\begin{array}{c}92 \\
(6]-130)\end{array}$ & $\begin{array}{c}7 \\
(1-17)\end{array}$ & $\begin{array}{l}120 \\
(8.6)\end{array}$ \\
\hline & Protomyctophum choriodon & 6.7 & $\begin{array}{c}7 \\
(4.9)\end{array}$ & $\begin{array}{c}64 \\
(44-102)\end{array}$ & $\begin{array}{c}2(1-7) \\
(0.6)\end{array}$ & 16 & - & - & - & - & - \\
\hline & Gymnoscopelus nicholsi & 33.3 & $\begin{array}{c}15 \\
(10.4)\end{array}$ & $\begin{array}{c}195 \\
(94-367)\end{array}$ & $\begin{array}{c}72 \\
(6-281)\end{array}$ & $\begin{array}{c}1078 \\
(43.3)\end{array}$ & 4.5 & $\begin{array}{c}5 \\
(7.9)\end{array}$ & $\begin{array}{c}151 \\
(108-180)\end{array}$ & $\begin{array}{c}24 \\
(8-36)\end{array}$ & $\begin{array}{l}119 \\
(8.6)\end{array}$ \\
\hline & Gymnoscopelus braueri & 6.7 & $\begin{array}{c}10 \\
(6.9)\end{array}$ & $\begin{array}{c}58 \\
(42-69)\end{array}$ & $\begin{array}{c}3 \\
(1-4)\end{array}$ & $\begin{array}{c}27 \\
(1.1)\end{array}$ & 4.5 & $\begin{array}{c}1 \\
(1.6)\end{array}$ & 116 & 17 & $\begin{array}{c}17 \\
(1.2)\end{array}$ \\
\hline & Gymnoscopelus fruseri & 3.3 & $\begin{array}{c}1 \\
(0.7)\end{array}$ & 51 & 35 & $\begin{array}{c}35 \\
(1.4)\end{array}$ & 13.6 & $\begin{array}{c}3 \\
(4.8)\end{array}$ & $\begin{array}{c}132 \\
(100-178)\end{array}$ & $\begin{array}{c}16 \\
(6-35)\end{array}$ & $\begin{array}{c}64 \\
(4.6)\end{array}$ \\
\hline & Gymnoscopelus bolini & - & - & - & - & - & 4.5 & $\begin{array}{c}3 \\
(4.8)\end{array}$ & $\begin{array}{c}198 \\
(192-206)\end{array}$ & $?$ & ? \\
\hline & Gymnoscopelus sp. & 10.0 & $\begin{array}{c}8 \\
(5.6)\end{array}$ & - & - & - & - & - & - & - & $\ldots$ \\
\hline & Unidentified Myctophidae & 3.3 & $\begin{array}{c}1 \\
(0.7)\end{array}$ & - & - & - & - & - & - & - & $\ldots$ \\
\hline Gadoidae & Micromesistius australis & 3.3 & $\begin{array}{c}17 \\
(11.8)\end{array}$ & $\begin{array}{c}168 \\
(134-198)\end{array}$ & $?$ & $?$ & - & - & - & - & - \\
\hline Channichtyidae & Champsocephalus gunnari & 6.7 & $\begin{array}{c}2 \\
(1.4)\end{array}$ & $\begin{array}{c}257 \\
(246-267)\end{array}$ & $\begin{array}{c}107 \\
(92-121)\end{array}$ & $\begin{array}{c}213 \\
(8.6)\end{array}$ & 4.5 & $\begin{array}{c}1 \\
(1.6)\end{array}$ & 351 & 302 & $\begin{array}{c}302 \\
(21.7)\end{array}$ \\
\hline \multirow[t]{2}{*}{ Macrouridae } & Unidentified Macrouridae & - & - & - & - & - & 4.5 & $\begin{array}{c}3 \\
(4.8)\end{array}$ & $?$ & $?$ & $?$ \\
\hline & Unidentified otoliths & 13.3 & $\begin{array}{c}4 \\
(2.8)\end{array}$ & - & - & - & 4.5 & $\begin{array}{c}2 \\
(3.2)\end{array}$ & - & - & - \\
\hline
\end{tabular}

availability and the diet of white-chinned petrels simply reflected this. The proportion of krill in white-chinned petrel diet in $1996(41 \%)$ and $1998(42 \%)$ was very similar and not greatly different from $1986(47 \%)$. However, the size was much smaller in 1996 (modal length 39-41 mm) and 1998 (mode $42 \mathrm{~mm}$ ) compared to that reported by Croxall et al. (1995) for 1986 (mode $55 \mathrm{~mm}$ ). Brierley et al. (in press) reported a mean krill length of $52.5 \mathrm{~mm}$ during February, $1986,15 \mathrm{~mm}$ greater than the mean $(37.8 \mathrm{~mm}$, range 32.0 43.1) for the following seven years for which data is available. Clearly white-chinned petrels fed on exceptionally large krill in 1986 but generally appear to feed preferentially on the larger krill available, presumably to increase the unit return per prey capture. The 1996 and 1998 data suggest that krill is indeed the single most important prey item to white-chinned petrels at South Georgia but that they are a versatile specie:;, well adapted to a broad-spectrum diet. They seem to be as adept in taking krill as fish and squid, and presumably favour krill whenever its abundance is sufficient to warrant the lower return per unit capture.

Although the diet was generally consistent between years, a few important differences in species composition are apparent. Myctophids dominated the fish diet in all years but the notothenid Patagonotothen guntheri was less abundant in 1996 and 1998 than in 1986. Croxall et al. (1995) thought it probable that white-chinned petrels obtained this species 
in 1986 mainly through associating with commercial fisheries in the Shag Rocks area (250 km east of Bird Island) to which Patagonotothen guntheri is restricted in the South Georgia region (Everson et al. 1992). Patagonotothen guntheri was fished there through the 1980 s, with a reported catch of 16000 tonnes in 1986 (Everson \& Mitchell 1991) but there has been no directed fishery for this species since 1990 . The most important notothenid in the diet in both 1996 and 1998 was Lepidonotothen larseni. This species frequently has been found in the diet of marine predators at South Georgia in recent years (Reid \& Arnould 1996, Berrow et al. in press) suggesting that it may have increased in abundance. Overall, the main fish prey of white-chinned petrels are species primarily dependent on krill e.g.Lepidonotothen larseni, Gymnoscopelus nicholsi, Electrona antarctica, rather than those mainly taking copepods and amphipods. Electrona carlsbergi, a predator of copepods and hyperiids, was more evident in the diet in 1998.

The squid Martialia hyadesi was the most commonly taken cephalopod species in 1986, accounting for one half of the mass of squid consumed (Croxall et al. 1995) but was not recorded in the present study. Illex argentinus occurred in the diet in both 1996 and 1998 but was not recorded by Croxall et al. (1995). Around the Falkland Islands on the Patagonian shelf there is a substantial fishery for Illex argentinus in which Martialia hyadesi occurs as a minor catch (González et al. 1997). Stocks of Illex argentinus are caught in large numbers each year but catches of Martialia hyadesi have fluctuated considerably since 1985 with the largest catch (c. 26000 tonnes) reported in 1986, the year this species was reported in the diet of white-chinned petrels (González et al. 1997).

\section{Provisioning rate and meal size}

The feeding frequency and meal size, as determined by daily weighing of chicks, varied between years. Chicks received on average around $130 \mathrm{~g}$ every 1.3 days in 1996 but $146 \mathrm{~g}$ every 1.9 days in 1998 . The two years outside of this study for which provisioning rate data are available are intermediate: $c .150 \mathrm{~g}$ was delivered every 1.8 days in 1979 (Croxall \& Prince 1980) and $167 \mathrm{~g}$ every 1.5 days in 1986 (Croxall et al. 1995). Actual feeding frequency will be influenced by how we determined double feeds to the chick on the same day, but as the method is consistent it is the relative frequencies that are important. Overall, mean meal size was consistent but feeding frequency varied; we presume this reflects that, like most Procellariiformes, white-chinned petrels only return to the nest to provision the chick when the adult has a full meal to deliver (Berruti et al. 1985, Hamer \& Hill 1993). In years when food is scarce, it presumably takes the adult bird longer to collect a full meal and thus feeding frequency to the chick declines, resulting in $19 \%$ less food being delivered to the chick during the fledging period in 1998 compared to 1996 and $46 \%$ less than in 1986. Although daily chick weighings were carried out over the same dates in 1996 and 1998, chicks had significantly lower body mass in 1998 . This could be due to chicks being older and thus heavier in 1996 or evidence of reduced growth rates in 1998 during early chick-rearing. The age of each chick weighed was not known but there is some evidence that adults laid later in 1998 compared to 1997 (S. Berrow unpublished data), which could be attributed to reduced food supply during the pre-egg period (Warham 1990). White-chinned petrels, due to their extended fledging period, cannot delay laying for too long if they are to complete chick-rearing before the start of the winter. Thus reduced provisioning rates in 1998 may reflect both the younger age of the chick as well as increased foraging effort (longer trips) by adults.

Most petrels return to their burrow to feed their chicks at night (Warham 1996). We found that the proportion of nocturnal and diurnal feeds varied between years with half the feeds delivered during the day in 1998. If adults are experiencing difficulties in obtaining food (as suggested by the reduced feeding frequency) then it may be necessary for them to return immediately to the burrow on obtaining a full meal for the chick without waiting for darkness, as this could extend the interval between meals up to 8-10 hours. However, this may increase the risk of predation or kleptoparasitism by brown skuas Catharacta loennbergi Mathews 1912. The exact time of feeding and the cost and benefit of day and night provisioning needs further study.

\section{Comparison with other seabirds at South Georgia}

Prior to the current study it was thought that white-chinned petrels and grey-headed albatrosses might have rather similar overall diet composition, lacking obvious specialization for any one particular class of prey and, within prey class, having some similarities in prey species composition. The new data for white-chinned petrels indicate that while overall diet composition and prey species may be rather similar, the squid Martialia hyades $i$ is not a consistent feature of white-chinned petrel diet. This is rather different from the grey-headed albatross, where $M$. hyadesi has accounted for over $70 \%$, by mass, of the squid component in the diet in four of the five years of sampling (Prince 1980, J. Xavier personal communication 1998). In 1998, however, M. hyadesi accounted for only $18 \%$ by mass of grey-headed albatross diet, being replaced by Galiteuthis glacialis (J. Xavier personal communication 1998), the squid which was also one of the most important in the white-chinned petrel diet in 1998.

\section{Response of white-chinned petrels to changes in krill availability}

The abundance and size of krill during the breeding season around South Georgia varies annually (Brierley et al. 1997, Reid et al. 1999). In years when krill abundance is low, widespread reproductive failure of krill-dependent predators at Bird Island has been reported (Croxall et al. 1988, Boyd 

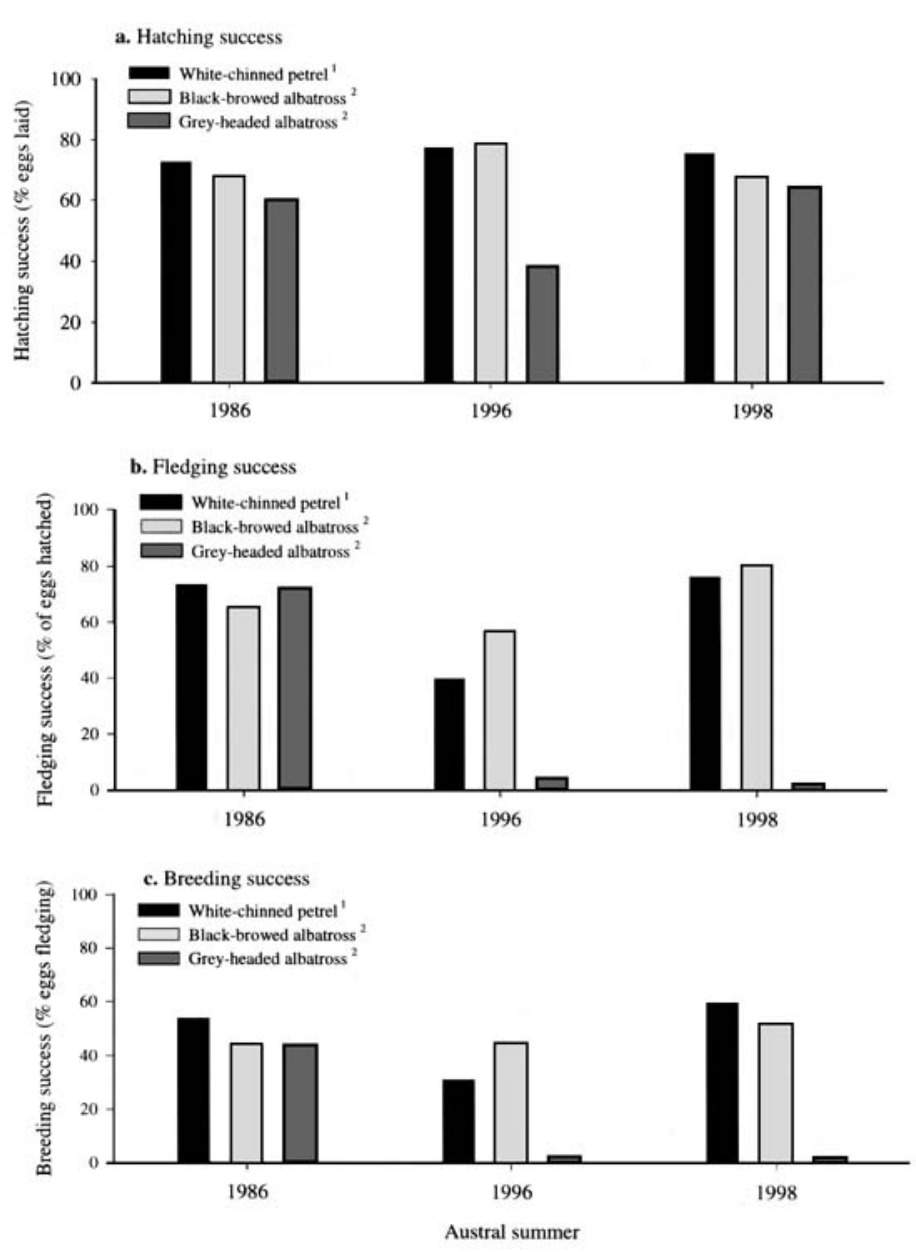

Fig 3. Breeding success of white-chinned petrels and blackbrowed and grey-headed albatrosses at Bird Island, South Georgia during the 1986, 1996 and 1998 summers. ('Hall 1987 and S. Berrow unpublished data, ${ }^{2}$ Prince et al. 1994 and British Antarctic Survey unpublished data)

et al. 1994, Croxall et al. 1999). In January 1996, krill occurred at densities of $26.7 \mathrm{gm}^{-2}$ off the north-west coast of South Georgia, which is similar to $29.7 \mathrm{gm}^{-2}$ reported in February 1986 (Brierley et al. in press). In the 1997/1998 summer, in the same area, krill densities were $5 \mathrm{gm}^{-2}$ in
October/November 1997 and $21.4 \mathrm{gm}^{-2}$ in January 1998.

The summer of 1996 was characterized by high breeding success of gentoo penguins Pygoscelis papua Forster 1781 ( 1.7 chicks fledged per pair), macaroni penguins Eudyptes chrysolophus Brandt 1837 (45\% successful nests) and black browed albatrosses (41\%, Fig. 3) and low mortality (19.5\%) of Antarctic fur seals Arctocephalus gazella Peters 1875 pups, indicating that krill was abundant throughout the breeding season. In 1998 the very low availability of krill in October/ November had clear effects on the breeding performance of many predators (Fig. 3, British Antarctic Survey unpublished data). Over $95 \%$ of gentoo penguins, which lay in October, failed during incubation. Breeding success of black-browed albatrosses, which also lay in October and whose success is closely linked to the availability of krill (Prince et al. 1994) was $1.6 \%$ in 1998 (Fig. 3) compared with a 17 year mean of 28.6\% (range: $0.0-63.6 \%$ ) (Prince et al. 1994); 62\% of the 1998 failures occurred during incubation. Peak parturition of Antarctic fur seals occurs in mid-December; mortality of pups in 1998 was $39 \%$ compared with a 13 year mean of $20.2 \%$ (range: $2.6-46.9 \%$ ). Foraging trips by breeding female fur seals were long (mean 6.5 days compared with 4.8 days for the period 1989-1994), which is indicative of increased foraging effort, typical of years with low krill availability (Boyd et al. 1994). Although krill abundance and length-frequency data (Reid et al. in press) indicate that South Georgia experienced an influx of large krill towards the latter half of the season, many of the earlier-breeding predators had already failed in their breeding attempt.

The proportion of krill in white-chinned petrel diet was similar between years. There was also no difference in meal mass but the foraging trip duration (longer by $46 \%$ ) resultcd in $19 \%$ less food delivered compared to 1996. This did not result in breeding success being very different between ycars and hatching and fledging success were also similar (Fig. 3), suggesting that adult birds were finding sufficient food during both the incubation and chick-rearing periods. Reduced provisioning rate may result in chicks fledging at lower body mass with subsequent reduction in survival (Sagar \& Horning, 1998) but this was not measured in the present study. Of possibly equal interest is the fact that white-chinned petrels

Table IV. Aspects of the feeding ecology and behaviour of white-chinned petrel and grey-headed and black-browed albatrosses breeding at Bird Island, South Georgia. Good year and bad year refer to years of relatively high local krill abundance and when krill was locally scarce, respectively.

\begin{tabular}{|c|c|c|c|c|c|c|c|}
\hline \multirow[t]{2}{*}{ Species } & \multicolumn{2}{|c|}{$\begin{array}{c}\text { Krill in } \operatorname{diet}^{1} \\
(\%)\end{array}$} & \multicolumn{2}{|c|}{$\begin{array}{l}\text { Breeding success }{ }^{\prime} \\
\text { (\% of eggs fledging) }\end{array}$} & \multirow[t]{2}{*}{$\begin{array}{l}\text { Time of } \\
\text { feeding }\end{array}$} & \multirow[t]{2}{*}{$\begin{array}{l}\text { Max diving } \\
\text { depth'(m) }\end{array}$} & \multirow[t]{2}{*}{$\begin{array}{c}\text { Foraging } \\
\text { range }^{4}\left(\mathrm{~km}^{2}\right)\end{array}$} \\
\hline & Good year & Bad year & Good year & Bad year & & & \\
\hline White-chinned petrel & 48 & 42 & 54 & 44 & Day and night & 12.8 & 124000 \\
\hline Grey-headed albatross & 16 & 2 & 60 & 27 & Day & 6.0 & $11970(1)$ \\
\hline Black-browed albatross & 39 & 5 & 31 & 3 & Day & 4.5 & 81500 \\
\hline
\end{tabular}

'Croxall et al. 1995, 1999, Berrow \& Croxall (this paper)

'Huin \& Prince 1997, Ashford et al. 1995, Barnes et al. 1997

${ }^{3}$ Huin 1994, Prince et al. 1994

${ }^{4}$ Wood et al. in press, Berrow et $a l$. in press 
fared much better than grey-headed albatrosses in 1998 (Fig. 3), the latter suffering their worst year for breeding success since records started in 1976 (Prince et al. 1994, Croxall et al. 1998).

The reason why white-chinned petrels are less influenced by the effects of krill shortage than some other South Georgia species is likely to reflect some combination of their diet (particularly scope for switching to prey other than krill), foraging methods and foraging range. We compare some of these attributes with two other South Georgia Procellariiformes in Table IV. This suggests that white-chinned petrels are considerably more versatile than albatrosses, particularly black-browed albatross, in when and where they can forage. Thus white-chinned petrels operate during both day and night, to greater depths and over larger areas. In years of krill scarcity they are able to switch to a range of other prey, including several taxa that are unlikely themselves to be extensively dependent on krill. (This probably differs from grey-headed albatross which relies mainly on fish and especially squid species that typically take much krill (e.g. Martialia hyadesi, Champsocephalus gunnari)). This switch may not be wholly cost-free as provisioning rate was somewhat reduced in 1998 and although fledging success seemed unaffected it is possible that chicks grew less well (and thereby fledged with smaller reserves). This would be similar to the response of macaroni penguin, which maintains breeding productivity in years of krill scarcity by switching to a diet of amphipods, albeit at the cost of fledglings being significantly lighter than in years of normal krill availability (Croxall et al. 1999).

In comparison with grey-headed albatross, our results suggest that some combination of the longer time available for foraging by white-chinned petrels, their larger foraging range, greater diving skills and ability to target squid species other than Martialia hyadesi in years when the latter is scarce may explain why white-chinned petrels fared better than greyheaded albatrosses in 1998.

\section{Acknowledgements}

We would like to thank Chris Hill, Richard Humpidge, Dominic McCafferty and Robbie Taylor for help with collecting samples. Squid remains were identified and measured by José Xavier; Martin White kindly provided unpublished length-mass regressions for Patagonotothen guntheri and Jon Watkins krill length-frequency data from RTM trawls at South Georgia. We are also grateful to Keith Reid, Paul Rodhouse and Martin White for commenting on earlier drafts of this paper and to Norbert Klages and two anonymous referees for critical review.

\section{References}

Ashford, J., Croxall, J.P., Rubilar, P.S. \& Moreno, C.A. 1995. Seabird interactions with longlining operations for Dissostichus eleginoides around South Georgia, April to May 1994. CCAMLR Science, 2, 111-121

Barnes, K., Ryan, P.G. \& Borx-Hansen, C. 1997. The impact of hake Merluccius spp. Iongline fishery off South Africa on Procellariiform seabirds. Biological Conservation, 82, 227-234.

Berrow, S.D., TAYlor, R.I. \& Murray, A.W.A. In press. Influence of sampling protocol on diet determination of gentoo penguins Pygoscelis papua and Antarctic fur seals Arctocephalus gazella. Polar Biology.

Berrow, S.D., Wood, A.G. \& Prince, P.A. In press. Foraging location and range of white-chinned petrels Procellaria aequinoctialis breeding in the South Atlantic. Journal of Avian Biology.

Berruti, A., Abams, N.J. \& Brown, C.R. 1985. Chick energy balance in the white-chinned petrel, Procellaria aequinoctialis. In SIEGFRIED, W.R., Condy, P.R. \& LAws, R.M., eds. Antarctic nutrient cycles and food webs. Berlin: Springer-Verlag, 460-465.

Boyd, I.L., ARnould, J.P.Y., Barton, T.\& Croxall, J.P. 1994. Foraging behaviour of Antarctic fur seals during periods of contrasting prey abundance. Journal of Animal Ecology, 63, 703-713.

Brierley. A.S., Watkins, J.L. \& Murray, A.W.A. 1997. Interannual variability in krill abundance at South Georgia. Marine Ecology Progress Series, 150, 87-98.

Brierley, A.S., Watkins, J.L., Goss, C., Wilkinson, M.T. \& Everson, I In press. Acoustic estimates of krill density at South Georgia during 11 austral summers between 1981 and 1998. CCAMLR Science.

Cooper, J., Fourie, A. \& Klages, N.T.W. 1992. The diet of the whitechinned petrel Procellaria aequinoctialis at sub-Antarctic Marion Island. Marine Ornithology, 20, 17-24.

Croxall, J.P. \& Prince, P.A. 1987. Seabirds as predators on marine resources, especially krill, at South Georgia, In Croxall, J.P., ed. Seabirds: feeding biology and role in marine ecosystems. Cambridge: Cambridge University Press, 347-367.

Croxall, J.P. \& Prince, P.A. 1994. Dead or alive, night or day: how do albatrosses catch squid? Antarctic Science, 6, 155-162.

Croxall, J.P., Prince, P.A. \& Reid, K. 1997. Dietary segregation of krill-eating South Georgia seabirds. Journal of Zoology (London), 242, $531-536$

Croxall, J.P., Rejo, K. \& Prince, P.A. 1999. Diet, provisioning and productivity responses of marine predators to differences in availability of Antarctic krill. Marine Ecology Progress Series, 177, $115-131$.

Croxall, J.P., Ricketts, C. \& Prince, P.A. 1984. Impact of seabirds on marine resources, especially krill, of South Georgian waters. In Whittow, G.C. \& Rahn, H., eds. Seabird energetics. New York: Plenum Publishing Corporation, 285-317.

Croxall, J.P., McCann, T.S., Prince, P.A. \& Rothery, P. 1988. Reproductive performance of seabirds and seals at South Georgia and Signy Island, South Orkney Islands 1976-1986: Implications for Southern Ocean monitoring studies, In Sahrhage, D., ed. Antarctic Ocean and resources variability. Berlin, Springer-Verlag, 261-285.

Croxall, J.P., Prince, P.A., Rothery, P. \& Wood, A.G. 1998. Population changes in albatrosses at South Georgia. In Robertson, G. \& Gales, R., eds. Albatross biology and conservation. Chipping Norton, Australia: Surrey Beatty \& Sons, 68-83.

Croxall, J.P., Hall, A.J., Hill, H.J., North, A.W. \& Rodhouse, P.G 1995. The food and feeding ecology of the white-chinned petrel Procellaria aequinoctialis at South Georgia. Journal of Zoology (London) 237, 133-150.

Everson, I. \& Mitchell, C. 1991. The fishery for Patagonotothen brevicauda guntheri in CCAMLR Subarea 48.3. Scientific Committee for the Conservation of Antarctic Marine Living Resources, Selected Scientific Papers 1990, 275-283. 
Everson, I., Parkes, G., Kock, K-H., Campbell, S., Cielniaszek, Z. \& SzLAKOWSKI, J. 1992. Fish stock assessment in subarea 4.8.3. Scientific Committee for the Conservation of Antarctic Marine Living Resources, Selected Scientific Papers 1991, 25-67.

González, A.F., Trathan, P.N., YaU, C. \& Rodhouse, P.G. 1997. Interactions between oceanography, ecology and fishery biology of the ommastrepid squid Martialia hyadesi in the South Atlantic. Marine Ecology Progress Series, 152, 205-215.

HALL, A.J. 1987. The breeding biology of the white-chinned petrel Procellaria aequinoctialis at South Georgia. Journal of Zoology (London), 212, 605-617.

HAMER, K.C. \& HiLl, J.K. 1993. Variation and regulation of meal size and feeding frequency in Cory's shearwater Calonectris diomedea. Journal of Animal Ecology, 62, 441-450.

Hecht, T.A 1987. Guide to the otoliths of southern ocean fishes. South African Journal of Antarctic Research, 17(1), 1-87.

HILL, H.J. 1990. A new method for measurement of Antarctic krill Euphausia superba Dana from predator food samples. Polar Biology, 10, 317-320.

Hurn, N. 1994. Diving depths of white-chinned petrels. Condor, 96, $1111-1113$.

JACKSON, S. 1988. Diets of the white-chinned petrel and sooty shearwater in the southern Benguela region, South Africa. Condor, 90, 20-28.

LIDDLE, G. 1994. Interannual variation in the breeding biology of the Antarctic prion Pachyptila desolata at Bird Island, South Georgia. Journal of Zoology (London), 234, 125-139.

Priddle, J., Croxall, J.P., Everson, I., Heywood, R.B., Murphy, E.J., Prince, P.A \& Sear, C.B. 1988. Large-scale fluctuations in distribution and abundance of krill - a discussion of possible causes. In Sahrhage, D., ed. Antarctic Ocean and resources variability. Berlin: Springer-Verlag, 169-182

Prince, P.A. 1980. The food and feeding ecology of grey-headed albatross Diomedea chrysostoma and black-browed albatross $D$. melanophris. Ibis, 122, 476-488.

Prince, P.A., Huin, N. \& Weimerskirch, H. 1994. Diving depths of albatrosses. Antarctic Science, 6, 353-354.
Prince, P.A., Rothery, P., Croxal.L, J.P. \& Wood A.G. 1994. Population dynamics of black-browed and grey-headed albatrosses Dionede melanophris and D. chrysostoma at Bird Island, South Georgia. Ibis 136, 50-71

REID, K. 1996. A guide to the use of otoliths in the study of predators at South Georgia. Cambridge: British Antarctic Survey, 39 pp.

REID, K. \& ARNould, J.P.Y. 1996. The diet of Antarctic fur seal Arctocephalus gazella during the breeding season at South Georgia Polar Biology, 16, 105-114.

ReID, K., CroXall, J.P. \& EdWARds, T. 1997. Interannual variation in the diet of the Antarctic prion Pachyptila desolata at South Georgia Emu, 97, 126-132.

Reid, K., Watkins, J.L., Croxali, J.P. \& Murphy, E.J. 1999. Kril population dynamics at South Georgia 1991-1997, based on data from predators and nets. Marine Ecology Progress Series, 177 $102-114$.

Reid, K., Barlow, K.E., Croxall, J.P. \& Taylor, R.I. In press Predicting intra-annual changes in the krill population at South Georgia. Marine Biology.

Rodhouse, P.G., Arnbom, T.R., Fedak, M.A., Yeatman, J. \& Murray, A.W.A. 1991. Cephalopod prey of the southern elephant seal, Mirounga leonina L. Canadian Journal of Zoology 70, 1007-1015.

S AGAR, P.M. \& Horning, D.S. 1998. Mass-related survival of fledgin: sooty shearwaters Puffinus griseus at The Snares, New Zcaland. lbis, 140, 329-339.

WARHAM, J, 1990. The petrels: their ecology and breeding system.s. San Diego: Academic Press, 440 pp.

WARHAM, J. 1996. The petrels: population biology and physiology of the petrels. San Diego: Academic Press, $613 \mathrm{pp}$.

Williams, R. \& McEldowney, A. 1990 . A guide to the fish otolith from waters off the Australian Antarctic Territory, Heard Island and Macquarie Island. ANARE Research Notes No. $75.173 \mathrm{pp}$

Wood, A.G., Naef-Daenzer, B., Prince, P.A. \& Croxall, J.P. In press Quantifying habitat use in satellite-tracked pelagic seabirds. application of kernel estimation to albatross locations. Journal of Avian Biology. 